\title{
Towards a Political Economy of Old Age*
}

\author{
ALAN WALKER $\dagger$
}

"An older person is expected to "accept" the "facts of ageing" "1

\section{ABSTRACT}

Although widespread poverty in old age has been recognized in Britain for at least 100 years, research on age and ageing has tended to concentrate on individual adjustment to old age and in turn, on narrow functionalist explanations of depressed social status. The elderly have been treated as a homogeneous group facing common problems. In contrast, an approach to ageing based on political economy will examine the relative social and economic status of different groups of elderly people as well as the relationship between the elderly and younger generations. Thus it is argued that poverty in old age is primarily a function of low economic and social status prior to retirement and the depressed social status of the retired, and secondarily, of the relatively low level of state benefits. Social policies which have failed to recognize inequality in old age and the causes of low economic and social status have therefore failed to tackle the problem of poverty and low incomes. The starting point for policy-makers should be the labour market and the social relationship between age and the labour market.

\section{Introduction}

The existence of poverty and deprivation amongst a substantial proportion of elderly people has been a recurring theme of research on ageing and social conditions in all industrial societies. ${ }^{2}$ In Britain, elderly people have been shown to be the largest group living in poverty ever since such information was collected systematically. ${ }^{3}$ Today just over one in four

* Revised version of a paper presented at the British Society of Gerontology Annual Conference, Aberdeen, ig8o.

$\uparrow$ Lecturer in Social Policy, Department of Sociological Studies, University of Sheffield, West Bank, Sheffield Sio 2TN, England. 
elderly people have incomes equal to or below the poverty line compared with one in twenty of non-elderly people. Altogether nearly two-thirds of the elderly, comprising 5.I million people, live in or on the margins of poverty, compared with one-fifth of the non-elderly. ${ }^{4}$ In the USA about one in every five elderly people have incomes below the federally established minimum. ${ }^{5}$ In Japan, nine-tenths of elderly people have incomes in the lower half of the income distribution. ${ }^{6}$ Data could be adduced to show a similar pattern in other industrial societies. Indeed, so common is the finding that it is for the most part, apparently, no longer considered remarkable.

Recent official research on retirement and on the social circumstances of elderly people do not discuss the problem of poverty. ${ }^{7}$ Poverty is not mentioned as a subject area in the most recent register of major social research on old age, which can presumably be taken, with duc caution, as a reliable barometer of research interest in the field of social gerontology. ${ }^{8}$ One of the 'most notable gaps in old age research', pin-pointed by an analysis of studies currently in progress, is income maintenance. ${ }^{9} \mathrm{Of}$ course gerontological researchers have not completely ignored the problem of poverty in recent years, ${ }^{10}$ but it certainly does not occupy the central focus that bald facts on the social condition of elderly people would appear to warrant. More importantly, this neglect stems in part from, and in turn reinforces, a forebearance of poverty in old age on the part of the state. For example, the official guide to the care of the elderly in Britain does not mention the problem, and the most recent green paper on elderly people refers to poverty once, in a ministerial foreword which seems to imply that the problem has been solved. ${ }^{11}$

While the major problem of poverty in old age has been ignored in recent official research and policy statements, low incomes have been accepted as an inevitable consequence of old age and therefore something to which elderly people must 'adjust'. ${ }^{22}$ This acceptance is legitimated through theorics of need based partly on age ${ }^{13}$ and narrowly functionalist theories of ageing. ${ }^{14}$ The latter suggest, in essence, that with increasing age people withdraw voluntarily from roles and relationships, or alternatively that they form a sub-culture, distinct from wider society. Either way elderly pcople are treated as a distinct homogeneous group who have, on the whole, adjusted to the ageing process. ${ }^{15}$ Age, like time itself, is a great leveller. The distinction between the 'young-old' and the 'old-old' may be seen as a variation, rather than a departure from these theories. ${ }^{16}$ Not surprisingly, pressure groups consisting predominantly of elderly people themselves, such as the Gray Panthers in the United States, have totally rejected such stcreotypes of ageing and the elderly. ${ }^{17}$ Despite this opposition, however, the stereotype of the clderly as a homogeneous group with 
special needs exerts a powerful influence on public attitudes and policies towards this group. ${ }^{18}$

Approaches to age and ageing based on the implicit assumption that the elderly can be treated as a distinct social group, in isolation from the rest of the social structure, have provided a totally inadequate basis for an explanation of the persistence of poverty in old age, and continue to obstruct the formation and application of social policies aimed at solving this problem. Thus little attention has been paid to the differential impact of social processes on elderly people. One important example of this failure is the long-standing neglect of women in studies on the transition to retirement. ${ }^{19}$ Secondly, by creating or reinforcing negative stereotypes through the portrayal of elderly people as a group with unique needs, there is a danger that a 'dysfunctional tension' will be set up between the elderly and the rest of society. ${ }^{20}$ Resentment towards the elderly has not been openly and consistently articulated in British society, but periodic expressions of alarm at the 'burden' of dependency may be seen as one result of socially divisive attitudes and policies. Although they reflect a crude ageism these attitudes cannot be dismissed simply in this fashion, because to do so would ignore significant variations in status and experience between different groups of elderly people. Alternative explanations of both widespread dependent status and deep-seated poverty are called for. In contrast to theories of ageing and the causes of dependent status based on the isolation of elderly people from social processes and values, an approach based on political economy locates the elderly firmly within the prevailing social and economic structure. Thus rather than concentrating on biologically based differences in ageing and individual adjustment to the ageing process, it would focus on the social creation of dependent status, the structural relationship between the elderly and younger adults and between different groups of the elderly, and the socially constructed relationship between age, the division of labour and the labour-market. The remainder of this paper attempts to sketch the outline of such an approach.

\section{Lifelong Social Status and the Social Organization of Production}

In contradistinction to analyses of the 'problems' of elderly people or of ageing the starting point for this explanation of poverty and dependent social status is the social institutions and processes which distribute resources prior to retirement. Primarily of course this means employment and the labour market, but there are also a wide range of other institutions, for example building societies, banks, insurance com- 
panies and social services, which play an important part in the differential allocation of resources to young as well as old people. Underlying these institutions there is the class structure itself which, to a large extent, determines opportunities, life chances and lifelong social status at birth. ${ }^{21}$ This social division of life chances is not inflexible, but whatever limited opportunities there are for social mobility, different cohorts of adults come to retirement with differentially distributed access to resources and therefore with different opportunities and post-retirement life chances.

Cross-national research carried out in 1962 revealed that in Britain and the United States white-collar retirement pensioners were less likely than the blue-collar group to receive state benefits, and much more likely to receive income from dividends and interest. ${ }^{22}$ The significance of class position at birth rather than at or just prior to retirement can be gauged by a comparison of social status across generations. Such a comparison was attempted in the analysis of data from a national survey of household resources and standards of living carried out in the UK in 1968-69. This showed that non-manual elderly people whose fathers had also been in non-manual occupations tended to have more resources than those whose fathers were in manual occupations. ${ }^{23}$ Comparison of the two extremes of this class - generational continuum, non-manual elderly with non-manual father and partly-skilled or unskilled manual elderly with father likewise, revealed that $4^{\text {I }}$ per cent compared with 63 per cent had net disposable household incomes below or on the margins of poverty; 7 per cent compared with 48 per cent had houschold net income worths (disposable income plus the annuitized value of assets) below or on the margins of poverty; and 2 per cent compared with 50 per cent had net unit assets of $£ 5,000$ or more. ${ }^{24}$ Those elderly pcople who had held semi-skilled or unskilled jobs and were from similarly low status families were the poorest of all. The influence of class of origin was also apparent in determining the resources, particularly assets, available to eldcrly people in the same social class. Thus, for example, elderly people in the skilled-manual group whose fathers were also skilled manual were slightly more likely to own their own homes than those in the same class whose fathers had been semi-skilled or unskilled.

So, an important determinant of living standards in old age is employment status and socio-economic group prior to retirement, which in turn, rests partly on social class of origin. During working life differential access is granted to social systems which distribute resources, the most important of which is employment. Those with high incomes from employment are more likely than others to accumulate savings, property and private pension rights. On the other hand those in low status jobs are more likely than other groups not only to be low paid but also to experience sickness and 
unemployment. The unemployment rate for skilled and unskilled workers is four times that for professional employees. ${ }^{25}$ Those wholly or predominantly excluded from the labour market, including people with disabilities and some women, are most likely to be amongst the very poorest in old age, a point I return to later.

The social division of employment and income opportunities under discussion here rests primarily on the social organization of production and the values underlying this organization. Under capitalist modes of production, in contrast to some agricultural economies, the ownership of productive resources is highly concentrated. ${ }^{26}$ As a result workers are dependent on owners of capital for the hire of their labour power, which means that their position is relatively pawerless, especially in the matter of tenure. The intervention of trade unions in this power relationship has created a wide variation in the degree of precariousness experienced by workers. Some groups, such as professional workers, are by contrast extremely powerful in determining their own tenure and conditions. Superannuation, discussed in detail below, underlines the precarious nature of the workers dependence on capital. Moreover the values on which capitalist distribution is based, inequality, independence, privatisation, the work ethic and monetary incentives, both enforce the view that individuals should provide for their own old age, and define the stigma attached to dependence on the state. Differential access, according to status, to occupational pensions, savings opportunities, asset ownership and so on mean that inequalities implicit in the capitalist mechanism of distribution are of fundamental importance in determining living standards in old age. State support, itself based primarily on the need to maintain monetary incentives, rather than to compensate for inequalities ensures that these differences are perpetuated. What is more, systems of distribution differ in the extent to which they protect individuals from economic and social changes. Thus because inflation enhances some forms of capital ownership, such as land and housing, and depletes fixed incomes and small savings, it reinforces inequalities. ${ }^{27}$

\section{Inequality and Poverty in Old Age}

Inequalities forged or reinforced in the labour-market are carried into retirement. Various changes in the structure and organization of employment over the last century, including the rise of shift-work and assembly line production; the increase in part-time work (especially amongst women) and the formation of professional groups, have widened labourmarket inequalities. Regardless of whether or not there are only two 
distinct, primary and secondary, labour-markets in Britain ${ }^{28}$ there is no doubt that labour-market experiences are socially divided with two distinct extremes. On the one hand a large number of jobs are boring, arduous or alienating, offering little or no prospects for promotion, few fringe benefits and relatively little security; while on the other there are relatively highly paid jobs offering a wide range of fringe benefits, a great deal of autonomy and security of tenure. These divisions under-pin post as well as pre-retirement experiences. The fact that inequalities in income (an important qualification) are slightly narrowed after retirement is due primarily to the relatively wide coverage of state benefits. ${ }^{29}$ Inequality between elderly income units is narrower in Britain than the United States and Denmark, but the levels of income are lower. ${ }^{30}$ Nevertheless there are wide inequalities amongst elderly people in British society based on the differential ownership of assets and right to income.

Occupational pensions are of fundamental importance in this structure of inequality and are one of the main reasons behind the emergence of 'two nations' in old age, forewarned by Titmuss twenty-five years ago. ${ }^{31}$ Two sources of inequality may be distinguished here. There is unequal access to occupational pensions, based primarily on socio-economic group and employment status, and secondly, there is inequality between generations of elderly people arising from changes in pension conditions and levels. The coverage of occupational pensions increased from 2.6 million employees in the I 930 s and stabilized at about I I.5 million employees in the $1970{ }^{32},{ }^{32}$ about half of the workforce. Some 2 million workers are not eligible for pension schemes because their employment is part-time or temporary, and a further I.7 million occupy ineligible jobs. The majority of those excluded from their employer's pension scheme ( 62 per cent) are manual employees. ${ }^{33}$ Not only do manual workers have restricted access to occupational pensions compared with non-manual groups but also if they receive pensions they are often on less favourable terms. For example, in both public and private sectors, manual workers are less likely than non-manual workers to receive lump sums on retirement, receive pensions that are based on final salary and to have their pension preserved if they change jobs. ${ }^{34}$ The mean amount of an occupational pension for professional and managerial workers is roughly five times that for unskilled manual workers. ${ }^{35}$ Turning to the second form of inequality arising from occupational pensions; as successive age cohorts of elderly people have become eligible for occupational pensions, and these have been increased, previous generations have become relatively deprived. Thus the median level of pensions in 1975 , for males aged under $6_{5}$ was $\&_{15} .00$ compared with $£ 6.00$ for those aged 70 and over. ${ }^{36}$

A second important source of inequality between elderly people is in 
labour-force participation. Those who continue to work after retirement age are less likely than the retired to experience poverty: in 1976 only 7 per cent of elderly families whose head was in paid employment had incomes on or below the poverty line, compared with 4 per cent of those whose head was not in employment. ${ }^{37}$ In the three-nation study carried out by Shanas and her colleagues, most of the elderly people in employment were in the middle or upper end of the distribution. ${ }^{38}$ The fact that the proportion of income units receiving employment income rises as total income rises has been confirmed by recent official research. Taking single person households first, amongst men aged 65 to $73,3^{\circ}$ per cent of those in work had net weekly incomes under $£_{30}$ compared with 82 per cent of the retired; for women aged 60 to 73 the figures were 53 per cent and 85 per cent. In two-person households, amongst men aged 65 to 73,3 per cent of those in work had net weekly family incomes of less than $£_{30}$ compared with 26 per cent of the retired; the figures for women aged 60 to 73 were 5 per cent and 28 per cent respectively. ${ }^{39}$

Labour-force participation amongst elderly people is dependent on a large number of factors, including socio-economic status, health, administrative regulations and custom, the most important of which are discussed later. In fact only a small proportion, about 12 per cent, of elderly people living in the community are in full or part-time work..$^{40}$ This proportion differs markedly according to age, sex and marital status. For example amongst men, 25 per cent of those aged $65^{-69}$ are employed compared with 3 per cent of those aged 80 and over. Elderly married men are more likely to be employed than non-married men, single women are more often employed than those who are or have been married. ${ }^{41}$ These differences in labour-force participation are, of course, reflected in differences in income, but regardless of employment status, single elderly people are more likely than married elderly people to experience poverty. For example, in $1968-9,82$ per cent of single (unmarried, widowed, divorced, separated) elderly people who had retired were living in or on the margins of poverty, compared with $6 \mathrm{r}$ per cent of married elderly people. ${ }^{42}$ Inequalities were even wider when assets were included: single men and single women were much less likcly than married persons to have assets of more than $£$ I 100 or to own their own homes. ${ }^{43}$

Inequalities in socio-economic status are based only partly on age. More significant is the denial or restriction of access to resources of people of advanced age. When taken together with factors already discussed the effect is to distinguish a severely disadvantaged group of elderly pcople of advanced age. There is a sharp diminution of resources with advanced age, regardless of marital status. Thus, for example, in $1968-69,4^{8}$ per cent of men aged $65^{-9}, 68$ per cent aged $70-9$ and 85 per cent of those 
aged 80 and over had incomes on or below the poverty line. For women in these age groups the figures were 63 per cent, 73 per cent and 86 per cent. ${ }^{44}$ The inclusion of assets reduced the proportion living below the poverty line, but the trend for those of advanced age to be poorest remained unmistakable. ${ }^{45}$ The fact that the number of persons aged 75 and over are expected to increase rapidly to 3.4 million by the turn of the century ${ }^{46}$ emphasises the magnitude of the social problem resulting from the social disadvantage of this group.

\section{Social Creation of Dependent status}

In addition to class position prior to retirement which is a major determinant of access to resources in old age, and the relative disadvantage of successive cohorts of elderly people, an explanation of reduced social status in old age must also take account of major differences between young and old and particularly the disproportionate impact of poverty on elderly pcople. The extent of this burden is summarized in the table below, showing the inequalities in income between old and young.

TABLE I. Percentage of individuals in families with incomes above or below the state's standard of poverty ${ }^{47}$

\begin{tabular}{lcccccc}
\hline & \multicolumn{6}{c}{ Household income as a percentage of supplementary benefit } \\
\cline { 2 - 7 } Family Type & $\begin{array}{c}\text { 10o or } \\
\text { less }\end{array}$ & $\begin{array}{c}100- \\
139\end{array}$ & $\begin{array}{c}140- \\
199\end{array}$ & $\begin{array}{c}\text { over } \\
200\end{array}$ & Total & $\begin{array}{c}\text { Number in } \\
\text { population } \\
\text { (thousands) }\end{array}$ \\
\hline $\begin{array}{l}\text { Elderly couple } \\
\text { man }\end{array}$ & 16 & 40 & 27 & 18 & 100 & 3,990 \\
$\quad$ woman & 26 & 36 & 23 & 17 & 100 & 770 \\
Non-elderly couple & 39 & 32 & 18 & 12 & 100 & 3,490 \\
$\quad$ no children & 2 & 5 & 19 & 73 & 100 & $9,59^{\circ}$ \\
$\quad$ couple with children & 4 & 17 & 40 & 39 & 100 & 28,010 \\
$\quad \begin{array}{l}\text { single parent } \\
\text { single person }\end{array}$ & 35 & 29 & 22 & 14 & 100 & 1,910 \\
All inclividuals & 6 & 13 & 32 & 49 & 100 & 5,050 \\
\hline
\end{tabular}

Of course household income is only one aspect in the overall distribution of resources which determines the relative position of different groups in the social and economic structure, but a similar pattern of inequality between old and younger adults could be demonstrated on the basis of information about assets, property, savings and income in kind from a wide range of social services, which buttress or directly substitute for 
income. ${ }^{48}$ The most significant fact underlying these inequalities is the relatively small proportion of elderly people who are economically active: 14 per cent of men aged 65 and over compared with $9^{2}$ per cent of those aged $16-64 .^{49}$ The importance of this difference is indicated by data from the latest Family Expenditure Survey: in 1977 some 77 per cent of households whose gross incomes were below $£ 25$ were retired, while at the other end of the income distribution, only 5 per cent of households whose gross incomes were $£ 200$ or more were retired. ${ }^{50}$ These income figures were reflected in the expenditure of different households: the average wcekly expenditure of retired households was $£_{4}$ o compared with $£ 82$ for the employed. ${ }^{51}$

The process of retirement, which results in an average fall in income of about one-half, ${ }^{52}$ is of immense significance in determining the structural relationship between young and old and the depressed social status of elderly people. Therefore a political economy of this process is an essential component of our explanation of poverty and dependency in old age. It is important to establish at the outset that 'old' age is socially defined, as the statutory retirement age. In a relatively short space of time, retirement has become a dominant social process in the lives of older people. This trend can be illustrated simply by reference to successive cohorts of those currently over retirement age. Four-fifths of those elderly people living in the community who are aged 85 and over continued working for some period after the statutory retirement age, compared with one-half of those aged from 75 to 84 and just over one-third of those aged $65-74 .^{53}$ Moreover the trend is distinguishable over very short periods of time. For example, betwcen $197 \mathrm{I}$ and 1978 , the proportion of males aged 60 to 64 who were retired rose from 6 per cent to 12 per cent; for those aged $65-69$ the proportion retired increased from 67 per cent to 73 per cent; for those aged 70 to 79,78 per cent to 87 per cent, but for those aged 80 and over 92 per cent to 85 per cent. ${ }^{54}$

Superannuation, like redundancy and unemployment before it, emphasises the dependence of workers directly or indirectly on capital and the socially divided nature of this dependent relationship. Some socioeconomic groups may continue working beyond the statutory retirement age and indeed, gain status for doing so, others are effectively excluded from labour-force participation at, or before, that fixed age. In the face of unemployment most workers are relatively powerless to oppose the social and economic forces which will detach them from employment, perhaps for a substantial period; in the face of bureaucratic regulation and institutionalized social custom, on top of economic imperative, elderly people are even more powerless to resist. Even so, 'a substantial minority' of elderly men and women would have liked to continue working beyond 


\section{$82 \quad$ Alan Walker}

retirement age but were not able to do so. ${ }^{55}$ In a recent study of retirement the main reason given by older workers for having difficulty getting a suitable job was the fact that they were 'too old' ${ }^{56}$ Not surprisingly, perhaps, those over the age of 65 have the highest degree of job satisfaction compared with other age-groups. ${ }^{57}$ Attachment to economic activity on the part of elderly people can be further demonstrated by the fact that in I 962 just over three-quarters of employed men aged $6_{5}$ and over said that they would 'never retire', ${ }^{58}$ and in 1976 three-fifths of men and seventenths of women said they would work as long as they could.

The tyrannical effect of age-barrier retirement can be seen not only in the exclusion of substantial numbers of older workers from labour-force participation but also in the changes in socio-economic status following retirement. As table two shows there is a dramatic downward shift in status after retirement age for both men and women.

TABLE 2. Percentage of employees in different socio-economic groups according to age and se $x^{59}$

\begin{tabular}{lcccrrr}
\hline Socio-economic group & \multicolumn{3}{c}{ Men } & & \multicolumn{3}{c}{ Women } \\
& $55-64$ & $65-73$ & All ages & $5^{0-59}$ & $60-73$ & All ages \\
\hline Employers and managers & 16 & 12 & 13 & 6 & 8 & 5 \\
Professional & 6 & 5 & 5 & 2 & - & I \\
Intermediate non-manual & 4 & 3 & 6 & 13 & 8 & 11 \\
Junior non-manual & 10 & 22 & 12 & 32 & 24 & 37 \\
Personal service & 1 & 2 & 1 & 18 & 18 & 13 \\
Foremen and supervisors & 6 & 1 & 4 & 1 & 1 & 1 \\
Skilled manual & 32 & 11 & 30 & 4 & 5 & 6 \\
Semi-skilled manual & 16 & 12 & 13 & 11 & 10 & 13 \\
Unskilled & 5 & 21 & 8 & 10 & 22 & 7 \\
Others/not answered & 5 & 10 & 9 & 3 & 4 & 7 \\
\hline Total & 100 & 100 & 100 & 100 & 100 & 100 \\
Number & 399 & 561 & & 199 & 454 & \\
\hline
\end{tabular}

Amongst both sexes there is a clear shift to unskilled work from skilled employment in the case of men, and from clerical work in the case of women. The industrial distribution of elderly people confirms this pattern of reduced social status, with a flow out of manufacturing industry and into distribution and other services. ${ }^{60}$ Furthermore elderly employees are much more likely than younger adults to work part-time, 64 per cent of men and 78 per cent of women compared with 4 per cent and 32 per cent respectively of all workers. ${ }^{61}$ Where the employment of elderly male workers was different from their main life job those working full-time were likely to be sales workers and those working part-time, labourers or cleaners. These dramatic changes in employment and socio-economic 
status are reflected in earnings. For example, only 8 per cent of full-time older workers aged from 55 to 64 had weekly earnings of under $£_{4} 0$ compared with 20 per cent of full-time workers aged 65 to 73 , the figures for women aged from $5^{\circ}$ to 59 and 60 to 73 were 37 per cent and 55 per cent. $^{62}$

A key factor in the creation of reduced social status amongst the elderly is therefore the increasing tendency to superannuate older workers at fixed ages. Just over one-half of men who retired at 65 and one-fifth of women who retired at 60 did so because of compulsory retirement, a further one-third and two-fifths retired of their own accord. ${ }^{63}$ Three-fifths of men and one-half of elderly workers who changed jobs at retirement age did so because of forced retirement; in addition 46 per cent of both men and women who gave up work at retirement age would have liked to go on working. ${ }^{64}$ Inequalities between different groups of elderly people are based primarily on socio-economic status prior to retirement, but the process of retirement superimposes reduced social status on the majority of elderly people. This process is legitimated in capitalist societies by a general devaluation of the skills, ability, knowledge and output of older workers. Even when 'productive', clderly people are likely to be relatively deprived in relation to other younger age groups. ${ }^{65}$ When superannuated into dependence or peripheral economic status elderly people are also likely to be relatively deprived compared to other groups amongst the elderly as well as younger adults.

In contradistinction to this analysis of the social formation of dependent status in old age some authorities have explained these changes in individualistic terms, or as part of a natural historical development towards a new form of society. For example, according to Neugarten:

Although the point has often been exaggerated, it is true that as a result of a slow historical process the older person is no longer the repository of wisdom which he may have been in simpler and more stable societics. More recently, he is also moving away from the role of economic producer - or the role of worker, as we have usually used that term. He has now become the user of leisure time. In that new role the young-old may be regarded as the first age group to reach the society of the future. ${ }^{68}$

Explanations such as these overlook inequalities between different groups of elderly people of the same age and the structural relationship between the elderly and the rest of society but, most importantly, they appear to ignore the fact that the relationship between age and the labour-market, which defines the economic role of elderly people in society, is socially determined and institutionalized through administrative regulation or customary practice. The dynamics of this social definition can be briefly illustrated by reference to two contrasting periods in Britain's economic 


\section{Alan Walker}

development. In the early 1950 os when manpower was in relatively short supply efforts were made to discourage retirement and tap the reserve labour-force of elderly workers. In 195 I Fred Lee, the Parliamentary Secretary to the Minister of Labour, made the following plea to older workers:

I ask them to think again: some of us may have become accustomed to the idea of retiring at a fixed age of $60-65$, but a man of 65 can today look forward to a long period of useful life. I have no doubt that many people would have a happier and healthier old age if they continue in their work a little longer rather than give up their routine and sink into a premature old age. ${ }^{67}$

Furthermore as Phillipson points out, these frequent appeals were accompanied and in part legitimated, by a body of academic and medical evidence stressing the detrimental effects of retirement. The National Advisory Committee on the Employment of Older Men and Women was established in I95 I to draw attention to the labour shortage and to encourage elderly people to defer retirement. In contrast, with the rise in unemployment in the 196os and especially in the 1970 s and various changes in the structure and organization of work, including the attraction of large numbers of married women into part-time work, retirement has been firmly established. In 1976 Greville Janner MP introduced the Sex Discrimination (Age of Retirement) Bill, arguing that:

There are more than a million unemployed people, of whom most are well and most are anxious to work. There are also about one million men aged between 60 and 64 , the majority of whom wish to retire but are unable to do so, and men who are anxious to have a decent and comfortable retirement are required by our incredible system to work on. ${ }^{88}$

In both periods, incidentally, attention was focussed on the economic and social 'burden' created by large numbers of dependent elderly people. Now, with the growth in unemployment in the 1970 os and early 1980 s a trend towards early retirement has been established by many employers and condoned officially through the Job Release Scheme. ${ }^{69}$ Just over onefifth of men and one-eighth of women interviewed in 1976 gave up work between the age of 50 and the statutory retirement age. ${ }^{70}$ The dominant reason amongst men for early retirement is sickness, a fact confirmed by data from the USA ${ }^{71}$ which together with unemployment accounts for nearly two-thirds of men who retired prematurely, and one-quarter of women. ${ }^{2}$ Ill-health is even more significant in very early retirement: 78 per cent of men who left work under the age of 60 and 33 per cent of women who left under the age of 55 gave ill-health as the reason. ${ }^{73}$

So, for a significant proportion of men and women retirement age is 
effectively lowered by sickness or unemployment. The differential distribution of these social problems has major implications for the resources available to different groups in old age. Semi-skilled and unskilled men and semi-skilled women are over-represented amongst early retirers. ${ }^{74} \mathrm{~A}$ recent study of early retirement found that even amongst 'voluntary' early retirers, whose main considerations were financial, two important factors were health and dissatisfaction with work or the job. ${ }^{75}$ Thus early retirement is primarily a function of socio-economic status and the social organization and structure of employment. Again it is not age as such that determines premature retirement but the social relationship between age, health and the labour-market. ${ }^{78}$ Some older workers suffer from redundancy, but others may be forced to leave work because their jobs are too strenuous or because their health has deteriorated under poor working conditions. Such restrictions are more common in manual than nonmanual employment, ${ }^{77}$ and therefore informal reductions in retirement age merely exacerbate inequalities between these groups and most importantly, they fail to answer directly the need for radical changes in the work processes and working conditions which create ill-health in older workers. ${ }^{78}$

\section{The Poor and the Poorest}

Early retirement, like age-barrier retirement, has a differential impact on older workers. The imposition of a fixed retirement age effectively excludes a substantial proportion of older workers from labour-force participation and is therefore a major determinant of economic and social status in old age. Of course there are a range of other factors which determine the exact impact of retirement, including socio-economic group prior to retirement, level of unemployment and type of employment, but the effect of a fixed retirement age is, at best, to freeze labour-market differentials. Some occupational groups are permitted to work beyond statutory retirement age, and not only earn additional income but also pension rights. Those most vulnerable to a loss of employment status at a fixed age are most likely to suffer redundancy, unemployment and illhealth earlier in their working lives. In addition job changes prior to retirement are often downwardly mobile. Those in the lowest socioeconomic groups are much less likely than others to have been doing the same job for most of their working lives: amongst men only 37 per cent of unskilled manual workers compared with 79 per cent of managerial and professional and 83 per cent of foremen and skilled manual groups. ${ }^{79}$ Secondly, with unemployment approaching 8 per cent of the workforce, the difficulty of finding alternative employment at age $5^{\circ}$ cannot be 
over-emphasized, but the problem for workers who are forced to leave jobs at the customarily accepted retirement age is even greater. Those living in areas where unemployment is above the national average face an impossible task. In the US the main reason given by elderly people for not looking for work was that they thought they could not obtain it. ${ }^{80}$ In other words some older workers are excluded from the labour-force prematurely by redundancy or ill-health and others at the statutory retirement age by the lack of employment opportunities.

The corollary to these trends in retirement is that an increasing proportion of elderly people are financially dependent to a greater or lesser extent on the state. More than nine-tenths receive all or part of their income in the form of state benefits. Cross-national research carried out in 1962 revealed that elderly income units in Britain were more likely to be totally dependent on the state for income compared with those in the US and Denmark. ${ }^{81}$ This dependency, and the levels of state benefits available to elderly people are secondary rather than primary causes of poverty in old age. The rates of social security benefits are determined in capitalist societies by the need to maintain monetary incentives and the work ethic and to restrain taxation; hence the value of the single person's retirement pension has remained at around one-fifth, and the married couple's around three-tenths, of average male gross industrial earnings since I948. Moreover, because of the complicated eligibility rules and stigma of meanstested supplementary benefit a substantial proportion of elderly people fail to claim the benefit they are entitled to. ${ }^{82}$ In view of the financial dependence and for many, deep poverty, associated with retirement it is not surprising that financial considerations are foremost in the minds of elderly people at retirement age. For example, the most frequent spontaneous reason for continued working beyond retirement age in Parker's study of retirement was connected with money. ${ }^{83}$ Furthermore, fourfifths of those men who had retired early and were still under pension age when interviewed said that money was the main thing they missed. ${ }^{84}$ Research by Burkhauser in the US showed that even amongst those older workers with poor health, changes in the value of pensions and earnings remained important factors in making the decision whether or not to retire. ${ }^{85}$

Retirement and the resulting dependence on relatively low incomes from the state imposes a depressed social and economic status on the elderly relative to younger adults. In addition the sources of inequality discussed previously, including receipt of an occupational pension, continued employment, marital status and age define the composition of a severely disadvantaged minority amongst the elderly. They are likely to be of advanced age, single, femalc, socially isolated and wholly dependent 
on supplementary pensions. Furthermore they are likely to be disabled to some extent, perhaps necessitating early withdrawal from the labourmarket, and have additional needs as a consequence. ${ }^{80}$ They are likely to be relatively deprived by virtue of their class position, but retirement and in turn, the diminution of resources with distance from retirement superimposed depressed social status on top of the disadvantage of class. The social factors underlying the creation of this depressed minority can be illustrated with reference to the status of elderly women.

As a result primarily of segregative employment policies, discriminatory social policies restricting access to resources on an equal basis to men, and depressed social status relative to men, which disadvantage them during their working lives, elderly women are disproportionately represented amongst the very poorest. ${ }^{87}$ In general women occupy a lower status in the labour-market than men. They are more likely to work part-time and partly as a consequence, to be low paid..$^{88}$ This pattern of disadvantage is repeated in the US. ${ }^{89}$ Married women who lcave the labour-market to do housework are relatively deprived in relation to other women as well as men. Married women are more likely than other women to have their access to money and other resources restricted by men. One important conscquence of their low employment status is that a smaller proportion of women than men are covered by occupational pension schemes, and when they are covered their pensions are lower. Moreover not all male occupational pensions include widows or full widows benefits. In 1975, for example, one-half of retired men compared with one-third of single women, but less than one-fifth of widows and under one-twentieth of married women received occupational pensions. The average pension received by men was $£ 8$ per week and by widows and single women, less than $\$ 6 .^{90}$ Only one in twelve very elderly widowed and single women (aged 80 and over) received occupational pensions compared with about one in two men. ${ }^{91}$

Segregative labour-market policies continue to disadvantage women beyond retirement age. Although women are slightly less likely than men to leave work at the statutory retirement age, a smaller proportion remain in full-time work beyond the age of $65 .{ }^{92}$ Women are much less likely than men to retire early, but much more likely to be impelled to do so by the need to look after someone other than their husband. Among those who gave up work between the ages of 40 and 59 the need to care for a sick or infirm relative was second only to health as a reason for doing so. ${ }^{93}$ Those who continue working are likely to receive lower incomes than men. ${ }^{94}$ Women are disproportionately represented amongst the elderly and especially the very old. As a consequence of increased age and restricted access to resources prior to and after retirement women are more 
likely than men to be wholly dependent on state benefits, ${ }^{96}$ and as table one showed, are more likely than other groups of elderly people to have incomes on or below the poverty line.

\section{Conclusion}

A great deal of influential research in social gerontology has tended to treat elderly people as a detached minority, independent from economic and political systems, and 'their problems' in terms of individual adjustment to ageing or retirement. Very little attention has been paid to the structural relationship between the elderly and the rest of society and the differential impact of social and economic institutions on elderly people. An examination of the resources available to elderly people reveals sharp inequalities between them and younger adults, as well as the existence of abject poverty amongst some of them. The persistence of illness and death resulting from hypothermia and malnutrition among elderly pcople are stark reminders of the deep-rooted nature of this problem..$^{96}$ At the other extreme some clderly people look forward to a relatively prosperous retirement with substantial pension rights and protection from inflation, although subsequent bereavement, sickness or disability may severely reduce living standards for these groups as well. Inequalities between old and young and amongst the elderly must be explained if they are to be counteracted.

The theme of this paper has been that poverty is a function of low economic and social status prior to retirement which restricts access to a wide range of resources, and secondly, of the imposition of depressed social status through retirement. ${ }^{97}$ Inevitably in such a brief account complex social relationships are simplified to some extent, but the dominant trends are unmistakable. Differential social and economic status in the labour-market presages a variety of post-retirement experiences. Despite evidence on the wide variety of capacities and knowledge among older workers there has been an increased tendency in recent years to exclude them from the labour-force at a fixed age. ${ }^{98}$ Moreover, the tyranny of age-barrier retirement provides the motivating force underlying a more general devaluation of the worth of elderly people in capitalist societies. When older workers are not required by capital or the agencies of capital they are superannuated and often encouraged to withdraw from the labour-force prematurely, and their skill, ability and knowledge is dismissed in derogatory terms such as 'obsolescent', 'unproductive' and 'inefficient'. There is no evidence, however, of a decline over time in the productive capacity of older workers at any given age, say 65 , so that the 
emergence and forceful application of age-barrier retirement must be explained primarily in terms of social and economic factors.

Similarly some authorities have identified widespread discrimination in capitalist societies on the basis of age. ${ }^{90}$ But to dismiss the depressed social status of the elderly simply in these terms is to ignore the complex, dynamic relationships between elderly people and the social organization of production and employment, which defines the boundaries of productive activity and in capitalist societies, therefore, dependency. Thus poverty and dependency in old age are not determined by chronological age, but the social construction of age through social institutions and policies and the social division of labour and class structure, which are also derived principally from the social organization of production and related processes.

I have attempted to explain the depressed social status of elderly people and particularly the persistence of poverty on the basis of social and economic forces at work in society as a whole, which stem ultimately from the dominant mode of production in British society. What are frequently identified as individual problems of consumption, low incomes, savings, inadequate stocks of consumer durables and so on, may be traced to the structure and organization of production and the particular pattern of inequality and social construction of age it generates. On this basis it is possible to begin to explore some aspects of the complex relationship between ageing and the social organization of production. The structural basis for the dependency of elderly people is one facet of the dependency of all labour on capital, but elderly people are particularly disadvantaged by developments in the organization of work, such as changes in industrial techniques and processes, the restructuring of capital, the growth of professions, the spread of credentialism and so on, which deny them access to an increasing range of jobs and confine them largely to low status employment. Changes like these in the industrial and educational sectors have contributed to the increasingly rigid age stratification of capitalist societies. ${ }^{100}$

Segregative social policies have combined to define, at a particular point in time, who are no longer useful to the process of production. The effect of this exclusion is to depress the status of elderly people relative to younger, productive adults and to sustain inequalities between different groups among the elderly. The superannuation of elderly workers from a life-time's productive activity, at a fixed age regardless of ability, is legitimated however, by institutionalized social policies which underplay the mandatory aspect of retirement and stress, for example, the poor rewards from continued employment, the need to make way to young people, the need to avoid accidents or ill-health and the need to enjoy leisure. ${ }^{101}$ 
This account has concentrated on the distributional impact of retirement and old age rather than the important psychological and personal problems of adjustment to job loss. Employment is not only the primary source of income and status in industrial societies, it also has a major integrative function in providing the basis for participation in a wide range of roles and relationships. So the exclusion of elderly workers from the labour-force reduces their range of social contacts. Moreover since work is the central activity of industrial societies, they also lose selfesteem. If, in addition, an elderly person internalizes society's negative stereotype of old age he or she is likely to become alienated. ${ }^{102}$ There is in short a tension betwcen 'the integrative impulses of informal primary relationships and segregative impulses of formal industrial society'. ${ }^{103}$

Just as the sociology and economics of ageing have tended to neglect the political economy of old age, so 'political gerontology' has concentrated on individual participation, voting and pressure group activities. ${ }^{104}$ The latter is not wholly surprising since much of the writing in this field derives from the pluralist tradition in the US, but this neglect means that major sources of inequality in old age and between the elderly and the rest of society have been relatively unexplored. A thoroughgoing approach based on political economy would combine sociological, economic and political analyses. For example, an examination of differential command over resources, would include the exercise of professional power over the lives of elderly people, the application of segregative social policies, benefits and services and the social creation of dependent status. In the absence of an analysis of the structural relationship between the elderly and the rest of society, social policies have failed to tackle the serious and persistent problem of poverty in old age. Instead low incomes have been accepted as a 'natural' result of old age and in some instances elderly people have been characterized as a 'burden'.

Social policies implicit in the approach to old age discussed in this paper would centre, first on the labour-market. One aspect of a concerted social policy to end poverty in old age would be flexible retirement, coupled with the pursuit of full employment and radical changes in the structure and organization of work, in order to prevent the use of flexible retirement to force a lower retirement age, ${ }^{105}$ and allow greater choice in retirement. Secondly, the social security system has failed to eradicate poverty in old age. There is a pressing need for policies which increase the valuc of retirement pensions relative to earnings and which do not depend on a declaration of means or dependent status. ${ }^{106}$ Thirdly, policies are required to ensure that elderly people control their own affairs, for example, in community services and residential accommodation and over pension funds. In sum, major social changes are necessary to lift the yokes of poverty and 
dependency from the elderly. These are 'facts' of ageing which elderly people have accepted for too long.

\section{NOTES}

I Stein E., 'What is Ageism?', in Gross, R., Gross B. and Seidman, S. (ed.) The Nezes Old: Struggling for Decent Ageing, New York, Anchor Books, 1978, p. 89 .

2 Sce, for example, Shanas, E., Townsend, P., Wedderburn, D., Friis, H., Milhøj, P. and Stehouwer, J., Old People in Three Industrial Societies, London, Routledge, 1980.

3 Booth, C., Pauperism: A Picture; and the Endowment of Old Age; An Argument, London, Macmillan, 1892; idem, The Aged Poor: Condition, London, Macmillan, I894; Townsend, P., Poverty in the United Kingdom, London, Allcn Lane, r979.

4 Layard, R., Piachaud, D. and Stewart M., The Causes of Poverty, Background Paper No. 5, Royal Commission on the Distribution of Income and Wealth, London, HMSO, 1978, p. I4. Here the 'poverty line' is defined by the supplementary benefit scale rate appropriate to families of different sizes. Those whose net houschold income does not exceed I40 per cent of this minimum are 'on the margins of poverty'.

5 Hendricks, J. and Hendricks, C. D., Ageing in Mass Society, Cambridge, Mass., Winthrop, 1977, p. 236.

6 Macda, D., 'Ageing in Eastern Society', in Hobman, D. (ed.) The Social Challenge of Ageing, London, Croom Helm, 1978, p. 6r.

7 Parker, S. R., Older Workers and Retirement, London, HMSO, r980; Hunt, A., The Elderly at Home, London, HMSO, 1978.

8 Todd, H., Old Age: A Register of Social Research, London, National Corporation for the Care of Old People, I979.

9 Ibid. p. vii.

Io Sec, for example, Butcher, H. and Crosbie, D., Pensioned Off, University of York, CDP Unit, 1978; Muller, C. F., 'Economic Roles and the Status of the Elderly' in Borgatta, E. F. and McClusky, N. G. (eds) Ageing and Society, London, Sage, 1980, pp. I7-41.

I I Central Office of Information, Care of the Elderly in Britain, I,ondon, HMSO, 1974; Department of Health and Social Security, A Happier Old Age, London, HMSO, 1978, p. 4.

I 2 DHSS, ibid.p. 2 r.

I3 Sce Wynn, M., Family Policy, Harmondsworth, Penguin Books, 1972, ch. 2.

I4 Cumming, E. and Henry, W., Growing Old, New York, Basic Books, 1961; Rose, A. M., 'The Subculture of the Ageing: A Framework in Social Gerontology', in Rose, A. M. and Peterson, W. A. (eds) Older People and Their Social World, Philadelphia, Davis, F. A., I965, pp. 3-16.

15 Hendricks, J. and Hendricks, C. D., op. cit. p. 105.

I6 Ncugarten, B. L., 'Age Groups in American Society and the Rise of the YoungOld', Annals of the American Academy of Political Science, Vol. 415, 1974, pp. I $87-98$.

17 Hudson, R. B., 'Old Age Politics in A Period of Change' in Borgatta, E. F. and McClusky, N. G., op. cit. p. 163 . 
I8 Walker, A., 'The Social Creation of Poverty and Dependency in Old Age', Journal of Social Policy, Vol. 9, 1, 1980, p. 51.

19 See, Phillipson, C., 'The Sociology of the 'Transition' in Johnson, M. L. (ed.) Transitions in Middle and Later Life, papers from the British Society of Gcrontology Annual Conference, 1979, p. 2.

20 Etzioni, A., 'Old Pcople and Public Policy', Social Policy, Vol. 7, I976, p. 21.

21 Westergaard, J. and Resler, H., Class in a Capitalist Society, Iondon, Heinemann, 1975; Goldthorpe, J., Social Mobility and Class Structure in Modern Britain, Oxford, Clarendon Press, I980.

22 Shanas, E., et al., op. cit. p. 406.

23 Ibid. p. 4 Io.

24 Townsend, P., op. cit. p. 803 .

25 Central Statistical Office, Social Trends, London, HMSO, ig8o, table 5.19.

26 See, Goody, J., 'Ageing in Nonindustrial Societies' in Baistock, R. and Shanas, E. (eds) Handbook of Ageing and the Social Sciences, New York, Reinhold, I976, pp. I I 7-29. Concentration on the capitalist mode of production should not be taken to imply that the inequality between old and young and amongst old people under discussion here is not also characteristic of other forms of society, but rather that the structure of inequality is relative to the prevailing relations of production. In Westergaard's terms 'Different modes of production involve different modes of incquality'. Westergaard, J., 'Class, Inequality and "Corporation"' in Hunt, A. (ed.) Class and Class Structure, London, Lawrence and Wishart, 1977, p. I65.

27 Lewis, P., et al., Inflation and Low Incomes, London, Fabian Society, 1975.

28 Doeringer, P. B. and Piore, M. J., Internal Labour Markets and Manpower Analysis, Lexington, D.C., Heath, 197 I.

29 Royal Commission on the Distribution of Income and Wealth, Lower Incomes, Report No. 6, Cmnd 7 r 75, London, HMSO, 1978, p. 99.

30 Shanas, E., et al., op.cit. p. $37 \mathrm{I}$.

31 Titmuss, R. M., Essays on 'the Welfare State' (second edition), London, Allen and Unwin, 1963, p. 74 .

32 Government Actuary, Occupational Pension Schemes 1975, London, HMSO, 1978 , p. 9.

33 Ibid.p. 17.

34 Ibid. pp. 47, 49, 73.

35 Royal Commission on the Distribution of Income and Wealth, op. cit. p. 378.

36 Government Actuary, op. cit. p. 21.

37 Royal Commission on the Distribution of Income and Wealth, op. cit. p. 375 .

38 Shanas, E., et al., op. cit. p. 374 .

39 Parker, S., op. cit. p. 3 I.

40 Hunt, A., op. cit. p. $5^{8 .}$

$4^{\text {I }}$ Ibid. pp. $5^{8-9}$.

42 Townsend, $P_{\text {., op. cit. p. } 795 .}$

43 Ibid. p. 796.

44 Ibid. p. 798.

45 Ibid. p. 799 .

46 Age Concern Research Unit, Profiles of the Elderly, Vol. I, Mitcham, Age Concern, 1977, p. 13.

47 Source: Layard, R., et al., op. cit. pp. I4-15.

$4^{8}$ Walker, A., op. cit. pp. 52-8.

49 Office of Population Censuses and Survcys, General Household Survey 1978, London, HMSO, 198o, p. 97. 
50 Department of Employment, Family Expenditure Survey 1977, London, HMSO, I978, p. 1 Io.

5 I Ibid.p. 87.

52 Central Policy Review Staff, People and their Families, London, HMSO, I 980 , p. 68.

53 Hunt, A., op. cit. p. 6r.

54 OPGS, op. cit. p. 94 .

55 CPRS, op. cit. p. 77 .

56 Parker, S., op. cit. p. 75.

57 OPGS, op. cit. p. IOI. The proportion working part-time is also a significant factor.

58 Shanas, E., et al., op. cit. p. 341 ; Hunt, A., op. cit. p. 61 .

59 Source: Parker, S., op. cit. p. 34 and Hunt, A., op. cit. p. 59.

6 o Hunt, A., op. cit. p. 59 .

61 Ibid. p. 6o. 30 hours or less.

62 Parker, S., op. cit. p .35.

63 Ibid. p. 13.

64 Hunt, A., op. cit. pp. 6r, 63 .

65 Townsend, P., op. cit. p. 795 .

66 Neugarten, B. L. op. cit. p. 198.

67 Quoted in Phillipson, C., The Emergence of Retirement, University of Durham, pp. $3 \mathrm{I}-2$.

68 Quoted in ibid. p. 45.

69 Department of Employment, Employment Gazette, March 1978, pp. 283-5.

70 Hunt, A., op. cit. p. 62 .

7 I Sec, Shanas, E., 'Health and Adjustment in Retirement', Gerontologist, Io, I970, pp. 19-2I; Schwab, K., 'Early Labor-Force Withdrawal of Men Participants Aged 58-63', in Irelan, L. M., et al., Almost 65: Baseline Data from the Retirement History Study, Washington D.C., Department of Health, Education and Welfare, 1976, pp. 43-56.

72 Parker, S., op. cit. p. Io.

73 Ibid.p. I4.

74 Ibid.p. 16.

75 McGoldrick, A. and Cooper, G. L., 'Voluntary Early Retirement - Taking the Decision', Employment Gazette, August 1980, p. 860.

76 According to a recent official survey of retirement: 'The biggest single influence on retiring under pension age was found to be age: the closer one is to $60 / 65$, the more likely one is to be retired'. Parker, S., op. cit. p. 13.

77 Schwab, K., op. cit. p. 46.

78 Sce for example, Walker, A., 'The Social Origins of Impairment, Disability and Handicap', Medicine in Society, 6, 2, 1980.

79 Hunt, A., op. cit. p. 65.

8o Muller, C. F., op. cit. p. 34 .

$8 \mathrm{I}$ Shanas, E., et al., op. cit. p. $4 \mathrm{I} 3$.

82 There is a similar problem of non-claiming in the US, see Hendricks, J. and Hendricks, C. D., op. cit. p. 236.

83 Parker, S., op. cit. p. 67.

84 Ibid. p. 22.

85 Burkhauser, R. V., 'The Pension Acceptance Decision of Older Workers', The Journal of Human Resources, Vol. xiv, p. 74.

86 Townsend, P., op. cit. pp. 815-19.

87 Wedderburn, 'The Old and the Poor', New Society, 22 July i965, p. 8. 


\section{Alan Walker}

88 Hurstfield, J., The Part-Time Trap, London, Low Pay Unit, 1979.

89 Hendricks, J. and Hendricks, C. D., op. cit. pp. 215-16.

go CPRS, op. cit. p. 77 .

9 I Government Actuary, op. cit. p. 22.

92 Parker, S., op. cit. pp. 4-5.

93 Hunt, A., op. cit. p. 63 .

94 Parker, S., op. cit. p. 3 I.

95 See McCoy, L. (cd.) Old, Proud and Poor, London, Wandsworth Task Force (undated), p. 25; Shanas, E., et al., op. cit. p. 364 .

96 Wicks, M., Old and Cold, London, Heinemann, 1978; Committee on Medical Aspects of Food Policy, Nutrition and Health in Old Age, London, HMSO, 1979, pp. 162-3.

97 See Walker, A., 'The Social Creation of Poverty and Dependency in Old Age', op. cit.; Townsend, P., Poverty in the United Kingdom, op. cit. Ch. 23.

98 There is some evidence to suggest that Britain has gone further than some other countries in the exclusion of older workers from labour-force participation, see Shanas, E., et al., op. cit. p. 292.

99 See for example, Gross, R., et al., op. cit. pp. 77-150.

100 See Goody, J., op. cit.; Rilcy, M. W., Johnson, M. and Foncr, A. (eds) Ageing and Society, Vol. 3, New York, Russell Sage, 1972.

Ior Comfort comments that 'Lcisure should occupy an occasional afternoon, not twenty years', Comfort, A., op. cit. p. 82.

I02 Hendricks, J. and Hendricks, C. D., op. cit. p. 224.

I03 Shanas, E., et al., op. cit. p. 426.

I04 Estes, C. E., 'Political Gerontology', Society, I5, 1978, pp. 43-9; Hudson, R. B., 'Old Age Politics in a Period of Change' in Bargatta, E. F. and McCluskey, N. G., op. cit. pp. 147-89.

I05 Muller, G. F., p. 32.

Io6 Etzioni, A., op. cit. p. 21. 